\title{
Changes in Adsorption Characteristics of Heavy Metals and Organic Pollutants Following Pyrolytic Treatment of Petroleum-Contaminated Dredged Sediment
}

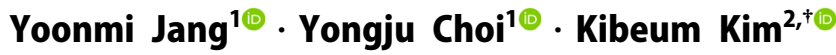 \\ ${ }^{1}$ Department of Civil and Environmental Engineering, Seoul National University \\ ${ }^{2}$ Water Cycle Research Center, Korea Institute of Science and Technology
}

(Received April 22, 2021; Revised June 17, 2021; Accepted June 21, 2021)

Objectives: This study investigated the changes in adsorption characteristics of dredged sediment for heavy metals and organic pollutants after petroleum contamination followed by pyrolytic treatment.

Methods: Pyrolytic treatment was conducted at two heating temperatures, $300^{\circ} \mathrm{C}$ and $500^{\circ} \mathrm{C}$, for 30 min using muffle furnace. Sediment spiked with No. 6 Fuel Oil at initial total petroleum hydrocarbon (TPH) concentrations of $5,000-50,000 \mathrm{mg} / \mathrm{kg}$ was used. Sorption experiments were conducted for heavy metals $(\mathrm{Cd}, \mathrm{Cu}, \mathrm{Pb}, \mathrm{Zn}, \mathrm{Ni}, \mathrm{Hg}$, As, Cr), phenanthrene and bisphenol A using clean sediment (sediment before the petroleum spiking) and pyrolyzed sediment.

Results and Discussion: Pyrolytic treatment at $500^{\circ} \mathrm{C}$ showed excellent $\mathrm{TPH}$ removal efficiency, resulting in the residual concentration of less than $50 \mathrm{mg} / \mathrm{kg}$ for all initial TPH contamination levels. High efficiencies (>98\%) were observed for the sorptive removal of $\mathrm{Cu}, \mathrm{Zn}$ and $\mathrm{Pb}$ in the aqueous phase for both the two sediments. The removal efficiencies of $\mathrm{Ni}$ and $\mathrm{Cd}$ from the aqueous phase using pyrolyzed sediment were $31 \%$ and $24 \%$ lower than those using clean sediment, respectively, due to the reduced oxygen-containing functional group content and specific surface area after the pyrolytic treatment. The sediment-water distribution coefficient $\left(\mathrm{K}_{\mathrm{d}}\right)$ and sediment organic carbon-water distribution coefficient $\left(\mathrm{K}_{\mathrm{oc}}\right)$ values of bisphenol A and phenanthrene in pyrolyzed sediment were considerably higher than in clean sediment due to the high organic compound sorption affinity exhibited by carbonaceous matter that was generated during the pyrolytic sediment treatment.

Conclusions: The capability of pyrolytic treatment of dredged sediment to notably improve its organic compound sorption capacity may be exploited for beneficial use of the treatment product. The product may be applied as fill and backfill, soil amendment, or in-situ sediment capping materials in highly industrialized areas where mitigation measures for organic contaminant migration are necessary.

Keywords: Dredged Sediment, Pyrolysis, Adsorption Characteristics, Heavy Metals, Bisphenol A, Phenanthrene, Adsorption

The Korean text of this paper can be translated into multiple languages on the website of http://jksee.or.kr through Google Translator.

Corresponding author
E-mail: kibeumkim@kist.re.kr
Tel: 02-958-5114 Fax: 02-958-5478
(c) 2021, Korean Society of Environmental Engineers
This is an Open Access article distributed under the terms of the Creative Commons Attribution Non-Commercial License (http://creativecommons.org/licenses/by-nc/4.0/) which permits unrestricted non-commercial use, distribution, and reproduction in any medium, provided the original work is properly cited. 


\title{
연구논문
}

\section{열분해에 의한 유류오염 준설 퇴적물의 중금속 및 유기오염물질 흡착특성변화}

\author{
장윤미 $^{1 \oplus} \cdot$ 최용주 $^{1 \oplus} \cdot$ 김기범 $^{2,+\oplus}$ \\ ${ }^{1}$ 서울대학교 건설환경공학부 \\ 2한국과학기술연구원 물자원순환연구센터
}

목적 : 본 연구는 유류로 오염된 준설 퇴적물의 열분해 정화 처리가 준설 퇴적물의 중금속, 유기오염물질 흡착특성 에 어떤 영향을 미치는지 알아보는 것을 목적으로 한다.

방법: 깨끗한 준설 퇴적물(Clean sediment)을 No. 6 Fuel Oil을 이용하여 총석유계탄화수소의 농도가 5,000- 50,000 $\mathrm{mg} / \mathrm{kg}$ 가 되도록 인공오염시킨 후 전기로를 이용해 $300^{\circ} \mathrm{C}$ 와 $500^{\circ} \mathrm{C}$ 의 두 온도조건에서 30 분간 열분해하였다. 깨끗 한 준설 퇴적물(유류오염 전)과 열분해 준설 퇴적물을 이용하여 중금속 $(\mathrm{Cd}, \mathrm{Cu}, \mathrm{Pb}, \mathrm{Zn}, \mathrm{Ni}, \mathrm{Hg}, \mathrm{As}, \mathrm{Cr})$ 과 phenanthrene 및 bisphenol A 오염수를 대상으로 흡착 특성을 분석하였다.

결과 및 토의 : $500^{\circ} \mathrm{C}$ 에서 열분해된 준설 퇴적물의 경우 모든 초기 $\mathrm{TPH}$ 농도 조건에서 잔류 TPH 농도가 $50 \mathrm{mg} / \mathrm{kg}$ 미만으로 나타나 열분해 정화 효율이 우수한 것을 확인하였다. $\mathrm{Cu}, \mathrm{Zn}, \mathrm{Pb}$ 오염수의 경우 Clean sediment와 Pyrolyzed sediment를 흡착제로 사용하였을 때 두 경우 모두 $98 \%$ 이상의 높은 용존 중금속 제거효율을 보였다. Ni, $\mathrm{Cd}$ 오염수의 경우 열분해로 인한 준설 퇴적물의 산소 포함 작용기량의 감소와 비표면적 감소로 인해 깨끗한 준설 퇴적물에 비해 열분해 준설 퇴적물의 흡착능이 각각 $31 \%, 24 \%$ 낮아졌다. Bisphenol A와 phenanthrene의 경우 열분 해 과정에서 준설 퇴적물 내 유류와 유기물을 전구물질로 사용하여 생성되는 탄화물질이 유기오염물질에 대한 높 은 흡착능을 갖고 있어 두 오염물질에 대한 흡착계수 $\left(\mathrm{K}_{\mathrm{d}}\right)$ 와 유기탄소 분배계수 $\left(\mathrm{K}_{\mathrm{oc}}\right)$ 값이 증가하였다.

결론 : 유류오염 준설 퇴적물을 열분해 처리로 정화하여 생산한 정화 준설 퇴적물은 높은 유기오염물질 흡착능을 지니므로, 유기오염물질이 확산될 가능성이 높은 유기화학공업단지에서 토양 개량제 또는 복토재로 사용되거나, 유기오염물질로 오염된 퇴적물의 원위치 피복 매질 등에 활용될 수 있을 것으로 기대한다.

주제어 : 준설 퇴적물, 열분해, 흡착 특성, 중금속, 비스페놀 에이, 페난트렌

\section{1. 서 론}

항만 개발 및 해상 항로 유지, 관리 등의 목적으로 국내에서 해마다 약 2 천만 $\mathrm{m}^{3}$ 의 준설 퇴적물이 발생하고 있다. 현재 많은 국가에서 준설 퇴적물을 매립과 해양투기 방법으로 처리 하고 있으며 런던협약으로 준설 퇴적물 내 오염물질의 농도가 각 국가에서 적용하는 기준을 초과하는 경우에는 해양투기를 이용한 처리가 금지되고 있다.1) 우리나라의 경우에는 준설 퇴 적물은 ‘폐기물 이외의 그 밖의 물질’로 분류되어 해양배출기 준을 만족하는 경우 일부 해양투기를 허용하고 있다.,3) 준설 퇴적물의 오염도가 높아 해양배출기준을 만족하지 못하는 경 우에는 환경부의 폐기물관리법 14 조에 따라 준설 퇴적물을 폐기물로 분류하여 지정된 장소에 매립하는 방식을 따르고 있다. 국내에서는 2000년부터 2014년도까지 96\%의 준설 퇴
적물이 전용 투기장에 매립 처리되었고 $0.07 \%$ 의 준설 퇴적물 만 유효활용되었다. ${ }^{4)}$ 준설 퇴적물 투기장을 이용한 매립 처리 의 경우 투기장 건설 및 관리에 막대한 비용이 소요되고, 투기 장 건설 시 다양한 생태종의 천연서식지가 파괴됨에 따라 이 와 관련된 천문학적인 사회적 및 환경적 비용이 발생한다. ${ }^{1)}$

다양한 산업활동 및 유류 오염 누출사고로 준설 퇴적물이 유류로 오염되는 경우가 종종 있다. ${ }^{1)}$ 유류오염물질을 완벽하 게 제거하지 않고 준설 퇴적물을 매립하거나 투기할 경우, 오 염물질이 확산되어 주변환경을 오염시키고 생태계에 부정적 인 영향을 미칠 수 있다. ${ }^{5)}$ Odetayo 등에 에 따르면 소수성 유기 오염물질(hydrophobic organic contaminants, HOCs)로 오염된 준설 퇴적물이 투기된 매립장에서 공기-물 분배계수(air-water partition coefficient)가 높은 저분자 다환방향족탄화수소 (polycyclic aromatic hydrocarbons, PAHs) 및 폴리염화바이페닐 
(polychlorinated biphenyls, $\mathrm{PCBs}$ )이 휘발되어 주변 대기를 오 염시킬 수 있다고 보고하고 있다. 뿐만 아니라, 유류로 오염된 준설 퇴적물이 매립지에 투기된 경우 혐기성 미생물 분해로 인해 메탄가스가 발생되어 지구온난화에 영향을 미칠 수 있 다. ${ }^{7)}$ 육상 매립 처리 방법의 경우 해마다 지속적으로 발생하 는 준설 퇴적물을 처리하기 위해 요구되는 공간 및 비용을 마련하는 것에 한계가 발생할 수 있으므로, 단순 매립 처리방 법을 대체할 지속 가능한 대안이 필요하다. ${ }^{8)}$

준설 퇴적물을 처리하기 위한 대안으로 이를 정화 후 유효 활용하는 방안에 대한 다양한 연구가 진행되고 있다. ${ }^{1)}$ 유류 로 오염된 토양 또는 준설 퇴적물을 정화하는 기술은 생물학 적 정화(bioremediation), 식물정화(phytoremediation) 등의 생 물학적 방법, 화학적 산화(chemical oxidation), 동전기정화 (electrokinetic remediation) 등의 화학적 방법, 토양세정(soil flushing), 토양증기추출(soil vapor extraction) 등의 물리학적 방법, 소각(incineration) 및 열탈착(thermal desorption) 등의 열적 방법이 있다. ${ }^{9)}$ 열적 방법을 이용한 유류 오염 토양- 퇴적 물 정화는 높은 효율로 다양한 범위의 석유계탄화수소 제거가 가능하며, 정화 시간이 짧고 정화에 필요한 공간 및 비용이 상대적으로 적다는 장점이 있다. ${ }^{10)}$ 특히, 최근에는 열분해 (pyrolysis) 기작을 활용하여 열처리하는 과정에서 유류오염물 질을 전구물질로 사용하여 높은 유·무기물질 흡착 잠재력을 갖춘 탄화물질(carbonaceous matter)을 형성하거나 유류를 액 상으로 회수하는 기술도 개발되고 있다. ${ }^{11}$

준설 퇴적물을 열적 방법에 의해 정화할 때 토성(soil texture), 광물학적 특성(mineralogy), $\mathrm{pH}$, 양이온 교환능(cation exchange capacity, CEC) 등 다양한 물리화학적 특성이 변화 될 수 있다. ${ }^{12,36)}$ 따라서 유류로 오염된 준설 퇴적물의 열적 방법에 의한 정화 후, 변화된 준설 퇴적물의 특성에 따라 유효 활용 방안(건설재료, 산업재료, 생태 서식지 조성 등)을 결정 할 필요가 있다. ${ }^{13)}$ 열적 방법 중 열분해의 경우 생성되는 탄화 물질이 높은 오염물질 흡착능을 지닐 것으로 기대되므로, 이 를 이용하여 열분해 정화 산물을 흡착제로 유효활용하는 연구 도 진행되고 있다. ${ }^{14,15)}$ 열분해 정화 준설 퇴적물을 중금속, 유 기오염물질 등을 배출하는 오염원 주변 부지 조성에 활용하여 오염물질의 이동성을 저감함으로써 오염물질 확산 방지와 주 변환경 개선을 꾀하는 방안 역시 고려해 볼 수 있다. 지금까 지 열분해의 유류오염 토양 및 퇴적물 정화효율을 고찰하는 연구 ${ }^{8,11,16)}$ 나 유기물 함량이 높은 준설 퇴적물을 열분해한 후 정화 산물의 오염물질 흡착 특성을 평가하는 연구 ${ }^{14,15,17)}$ 는 몇 몇 연구진에 의해 수행된 바 있다. 또한 Ahmad 등 ${ }^{18)}$ 은 열분해 과정에서 준설 퇴적물의 미세공극률, 유기물의 소수성 등이 달라지고, 이러한 차이가 유·무기 오염물질의 흡착능의 차이 와 깊이 연관된 것을 확인하였다.

준설 퇴적물은 중금속과 유류오염물질로 복합 오염되어 있 는 경우가 많지만 본 연구에서는 산업 활동 및 유류 오염 누출
사고로 인해 유류함량이 높은 준설 퇴적물을 분석하는 것에 중점을 두었다. 이를 바탕으로 열분해 전후 준설 퇴적물의 각 오염물질의 흡착특성 변화와 물리화학적 특성 변화의 연 관성을 분석하여 열분해 과정에서 오염물질 흡착특성이 변화 하는 주요 원인을 파악하고자 한다. 또한 유류로 오염된 준설 퇴적물을 열분해를 통해 오염물질을 제거한 후, 준설 퇴적물 의 중금속 $(\mathrm{Cu}, \mathrm{Cd}, \mathrm{Ni}, \mathrm{Pb}, \mathrm{Zn}, \mathrm{Hg}, \mathrm{As}, \mathrm{Cr})$ 과 유기오염물질 (bisphenol A, phenanthrene)의 흡착 실험을 통해 적절한 준설 퇴적물의 처리 및 재활용 가능성에 대해 평가하고자 한다.

\section{2. 재료 및 방법}

\section{1. 준설 퇴적물 시료 채취 및 열분해}

본 연구에서 사용한 준설 퇴적물은 인천광역시 강화도에서 채취한 뒤 풍화건조하여 $2 \mathrm{~mm}$ 체로 거른 후 실험 전까지 $4^{\circ} \mathrm{C}$ 에서 냉장 보관하였다. 준설 퇴적물을 유류로 인공오염시키 기 이전 오염시킬 유류의 투여량과 석유계총탄화수소(total petroleum hydrocarbons, TPHs) 함량의 관계를 알아보기 위해 다음 예비실험을 실시하였다. 준설 퇴적물에 No. 6 Fuel Oil을 $2,500 \mathrm{mg} / \mathrm{kg}, 5,000 \mathrm{mg} / \mathrm{kg}, 8,000 \mathrm{mg} / \mathrm{kg}, 1,000 \mathrm{mg} / \mathrm{kg}$ 의 중량 비만큼 투여하여 오염시킨 후 TPH 함량을 토양오염공정시 험기준의 석유계총탄화수소-기체크로마토그래피 분석법 ${ }^{19)}$ 에 따라 분석하였다. 그 결과, No. 6 Fuel Oil 중량비 2,500 $\mathrm{mg} / \mathrm{kg}, 5,000 \mathrm{mg} / \mathrm{kg}, 8,000 \mathrm{mg} / \mathrm{kg}, 10,000 \mathrm{mg} / \mathrm{kg}$ 일 때의 TPH 함량이 각각 $1,394 \mathrm{mg} / \mathrm{kg}, 3,183 \mathrm{mg} / \mathrm{kg}, 4,424 \mathrm{mg} / \mathrm{kg}, 6,212$ $\mathrm{mg} / \mathrm{kg}$ 임을 확인하였다. 이 결과를 이용하여 No. 6 Fuel Oil의 중량과 $\mathrm{TPH}$ 함량의 관계에 대한 선형 회귀식을 작성하고, 이 회귀식을 이용하여 준설 퇴적물의 $\mathrm{TPH}$ 농도가 $5,000 \mathrm{mg} / \mathrm{kg}$, $20,000 \mathrm{mg} / \mathrm{kg}, 50,000 \mathrm{mg} / \mathrm{kg}$ 이 되도록 오염시켰다. 그 후 오 염된 준설 퇴적물을 정화하기 위해 길이, 폭, 넓이가 각각 13 $\mathrm{cm}, 8 \mathrm{~cm}, 24 \mathrm{~cm}$ 인 Steel Case 내부에 내열 용기를 넣은 뒤 준설 퇴적물 $50 \mathrm{~g}$ 을 담았다. 그 후 내열 용기 뚜껑을 닫고 Steel Case의 Headspace를 질소 가스로 Purging하여 무산소 Headspace 조건을 조성하였다. 열분해는 전기로(electric muffle furnace)를 이용하여 이 무산소 조건에서 30 분간 $300^{\circ} \mathrm{C}$ 와 $500^{\circ} \mathrm{C}$ 의 온도로 실시하였다(Fig.1).

\section{2. 준설 퇴적물 흡착능 평가}

\subsection{1. 중금속 흡착능}

분석 대상인 $\mathrm{Cd}(\mathrm{II}), \mathrm{Cu}(\mathrm{II}), \mathrm{Pb}(\mathrm{II}), \mathrm{Zn}(\mathrm{II}), \mathrm{Ni}(\mathrm{II}), \mathrm{Hg}(\mathrm{II}), \mathrm{As}$ (III), $\mathrm{Cr}(\mathrm{VI})$ 을 각각 탈이온수에 녹여 $100 \mathrm{mg} / \mathrm{l}$ 오염수로 만든 후 $0.1 \mathrm{M} \mathrm{HNO}_{3}$ 를 이용하여 중금속으로 오염된 용액의 $\mathrm{pH}$ 가 5.0 이 되도록 보정하였다. $50 \mathrm{ml}$ 코니컬 튜브에 유류로 오염 시키지 않은 깨끗한 준설 퇴적물(clean sediment)과 No. 6 Fuel Oil을 이용하여 $\mathrm{TPH}$ 농도가 $50,000 \mathrm{mg} / \mathrm{kg}$ 이 되게 퇴적물을 오염시킨 후 무산소 조건, $500^{\circ}$ 에서 30 분간 열분해한 준설 퇴 


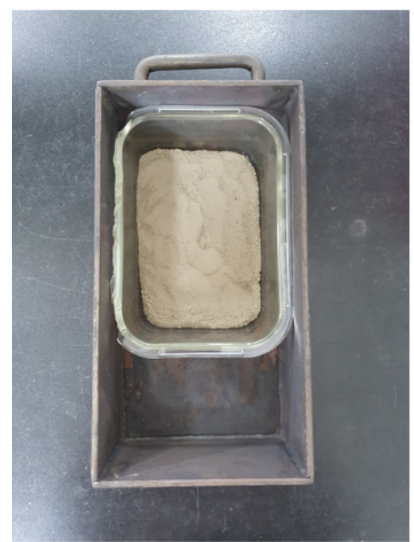

(a)

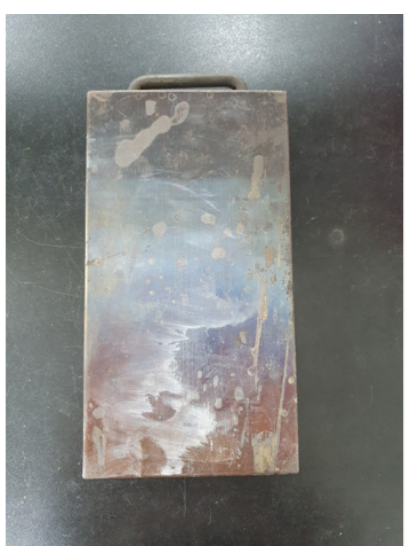

(b)

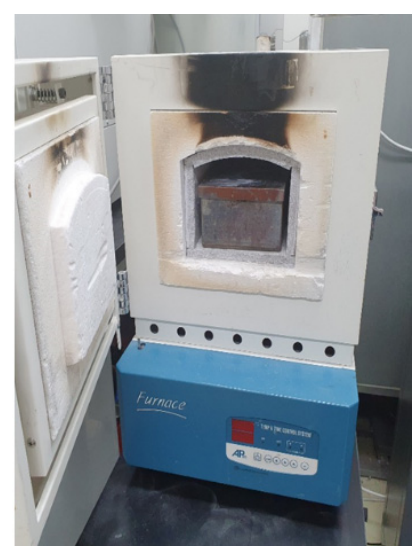

(c)

Fig. 1. Photos illustrating the experimental procedure employed in the current study: (a) sediment placed in a heat-proof container that is placed on a steel case, (b) the steel case after purging the inner atmosphere using nitrogen gas and covering with a lid, (c) the steel case ready for pyrolytic treatment in an electric muffle furnace.

적물(pyrolyzed sediment)을 각각 담은 후 중금속 오염수를 주 입하고 $180 \mathrm{rpm}$ 에서 24시간 동안 수평 교반하였다. 이때 $\mathrm{Cd}$, $\mathrm{Cu}, \mathrm{Pb}, \mathrm{Zn}, \mathrm{Ni}$ 흡착 평가일 경우 준설 퇴적물 $2 \mathrm{~g}$ 에 오염수 $10 \mathrm{ml}$ 를 주입하였으며, $\mathrm{Hg}, \mathrm{As}, \mathrm{Cr}$ 흡착 평가일 경우 준설 퇴적물 $0.5 \mathrm{~g}$ 에 오염수 $25 \mathrm{ml}$ 를 주입하였다. 교반이 끝난 후, 원심분리기로 $14,000 \mathrm{~g}$ 에서 10 분간 고액분리를 실시하고, 0.45 $\mu \mathrm{m}$ Syringe Filter를 이용하여 액상 시료를 획득하였다. 채취한 액상 시료의 중금속 농도는 유도결합플라스마-원자방출분광기 (inductively coupled plasma-mass spectrometry; 7800 ICP-MS, Agilent Technologies, USA)로 분석하였다. 모든 중금속 흡착 실험은 3 회 반복하였으며, 준설 퇴적물 또는 정화 준설 퇴적 물의 중금속 흡착능은 아래의 식 (1)을 이용하여 계산하였다.

$$
\text { 퇴적물의 중금속 흡착능(\%) }=\frac{C_{0}-C_{e}}{C_{0}} \times 100
$$

여기서 $C_{0}$ 는 중금속 오염수 내 초기 중금속 농도 $(\mathrm{mg} / \mathrm{l}), C_{0}$ 는 24 시간 교반 후 평형상태에서의 오염수 내 중금속 농도 $(\mathrm{mg} / \mathrm{l})$ 를 의미한다.

\subsection{2. 유기오염물질 흡착능}

Bisphenol A 흡착 실험을 위하여 준설 퇴적물 $0.4 \mathrm{~g}$ 과 탈이 온수에 bisphenol A를 $100 \mathrm{mg} / \mathrm{l}$ 농도로 녹인 용액 $8 \mathrm{ml}$ 를 10 $\mathrm{ml}$ Serum Bottle에 주입한 뒤 $150 \mathrm{rpm}$ 으로 7일간 수평 교반하 였다. 교반이 끝난 후 $0.45 \mu \mathrm{m}$ Syringe Filter를 이용하여 여과 한 용액을 고성능 액체크로마토그래피(high performance liquid chromatography; HPLC, YL 9100 Plus, Youngin, Korea)로 분 석하였다. HPLC의 컬럼은 $\mathrm{C} 18(250 \mathrm{~mm} \times 4.6 \mathrm{~mm}, 5 \mu \mathrm{m})$ 을 사용하였으며 이동상은 메탄올:탈이온수 혼합용액( $70: 30, \mathrm{v}: \mathrm{v})$ 를 사용하고 유속은 $1 \mathrm{ml} / \mathrm{min}$ 로 설정하였다.

Phenanthrene은 물에 대해 용해도가 낮아 기존의 오염수를 제조하여 흡착하는 실험 방법을 따르기 어려웠기 때문에 상 (phase)간의 분배 계수를 이용하여 간접적으로 용존된 오염물 의 농도를 추정하는 수동형 샘플링(passive sampling) 기법을 이용하였다. ${ }^{20)}$ 먼저 $250 \mathrm{ml}$ 메탄올:탈이온수 혼합용액(90:10, $\mathrm{v}: \mathrm{v})$ 에 phenanthrene $1.775 \mathrm{~g}$ 을 녹인 뒤 $20 \mathrm{ml}$ 갈색 병(amber vial)에 제조한 용액을 주입하였다. 그 뒤 수동형 샘플러 (passive sampler)로 사용할 $51 \mu \mathrm{m}$ 두께의 저밀도 폴리에틸렌 (low density polyethylene, LDPE; Brentwood Plastics, St. Louis, MO, USA)을 가로 $1 \mathrm{~cm}$, 세로 $0.5 \mathrm{~cm}$ 의 조각으로 잘라 phenanthrene 오염수가 들어있는 $20 \mathrm{ml}$ 갈색 병에 9개를 넣고 일주일 동안 $180 \mathrm{rpm}$ 에서 수평 교반하였다. 이후 LDPE 조각 을 꺼내어 표면에 남은 용액을 Kimwipes로 제거하였다. 총 9 개의 조각 중 3 개의 조각은 phenanthrene로 오염된 LDPE의 초기 농도를 구하기 위해 사용하였다. LDPE에 존재하는 phenanthrene의 추출은 LDPE 조각 1 개를 $2 \mathrm{ml}$ 갈색 병에 넣 고 $2 \mathrm{ml} \mathrm{Hexane}$ 을 추가한 후 하루 동안 교반하는 방법을 사용 하였다. 나머지 6 개의 LDPE 조각은 준설 퇴적물의 흡착능을 평가하는 데 사용하였다. 2 개의 $20 \mathrm{ml}$ 갈색 병에 LDPE 조각 을 각각 3 개씩 넣고 $0.1 \mathrm{~g} / \mathrm{l} \mathrm{NaN}_{3}$ 수용액 $20 \mathrm{ml}$ 를 주입한 후 하나의 병에는 Clean Sediment $2.0 \mathrm{~g}$ 을, 나머지 한 병에는 Pyrolyzed Sediment $2.0 \mathrm{~g}$ 을 넣었다. 이후 LDPE가 포함된 이 준설 퇴적물 Slurry를 일주일 동안 $180 \mathrm{rpm}$ 으로 수평 교반하 였다. 교반 이후에는 LDPE 조각을 꺼내어 표면의 물기를 제 거하고 잔류하는 phenanthrene을 위에 제시된 방법과 동일하 게 추출하였다. 추출액 내 phenanthrene 농도는 가스크로마토 그래피-질량분석기(gas chromatography-mass spectrometry; GC-MS, Agilent Technologies, USA)로 측정하였다. 컬럼은 HP-5MS $(30 \mathrm{~m} \times 250 \mu \mathrm{m}, 0.25 \mu \mathrm{m})$ 을 사용하였으며 Split Ratio는 10:1, Split Flow는 $10 \mathrm{ml} / \mathrm{min}$, 주입 용량은 $1 \mu \mathrm{L}$ 로 설정하였다. 운반 기체(carrier gas)는 헬륨 가스를 사용하였으 며, 운반 기체의 유속은 $1 \mathrm{ml} / \mathrm{min}$ 으로 설정하였다. 컬럼 오븐 온도는 $100^{\circ} \mathrm{C}$ 에서 2 분간 유지시킨 뒤 $150^{\circ} \mathrm{C}$ 까지 분당 $10^{\circ} \mathrm{C}$ 로 
상승시켜 3 분간 유지되었으며, 분당 $20^{\circ} \mathrm{C}$ 로 $250^{\circ} \mathrm{C}$ 까지 최종 적으로 승온시켜 총 15 분 안에 분석될 수 있도록 진행하였다. 모든 유기오염물질 흡착 실험은 3회 반복하였으며, 교반을 종 료한 시점에서 준설 퇴적물에 흡착된 phenanthrene의 농도는 phenanthrene의 물질수지식인 아래 식 (2)를 통해 계산하였으 며, 준설 퇴적물과 물 간의 흡착 평형상수는 식 (3)을 통해 계산하였다. 준설 퇴적물 내 유기탄소와 물 간의 분배계수는 식 (4)를 통해 계산하였으며, LDPE와 물 간의 phenanthrene 분배계수 $\left(\mathrm{K}_{\mathrm{PE}}\right)$ 는 $^{21)}$ 실험으로 얻은 값을 사용하였다.

$$
\begin{aligned}
& C_{P E, 0} \times M_{P E}=\left(C_{P E, t} \times M_{P E}\right)+\left(C_{w} \times V_{w}\right)+\left(C_{S} \times M_{s}\right) \\
& K_{d}=\frac{C_{s}}{C_{w}} \\
& K_{o c}=\frac{K_{d}}{f_{o c}}
\end{aligned}
$$

$C_{Z P E, 0}$ : 초기 $\mathrm{PE}$ 내의 Phenanthrene 농도 $[\mathrm{mg} / \mathrm{g}]$

$C_{P E, t}: \mathrm{t}$ 시간이 흐른 뒤 $\mathrm{PE}$ 내의 Phenanthrene 농도[mg/g]

$C_{s} \quad$ : 준설 퇴적물에 흡착된 Phenanthrene 농도[mg/g]

$M_{P E} \quad: \mathrm{PE}$ 의 무게 $[\mathrm{g}]$

$M_{s} \quad$ : 준설 퇴적물의 무게 [g]

$V_{w} \quad$ : 물의 부피[L]

$K_{d} \quad$ : 준설 퇴적물의 평형 상수 $[\mathrm{ml} / \mathrm{g}]$

$K_{o c}$ : 준설 퇴적물 내 유기탄소-물 간의 분배계수 $[\mathrm{ml} / \mathrm{g}]$

$f_{o c} \quad$ : 준설 퇴적물 내 유기탄소 함량[\%]

\section{3. 준설 퇴적물 물리화학적 특성 및 표면 분석}

준설 퇴적물의 표면 작용기는 푸리에 변환 적외선 분광기 (fourier-transform infrared spectroscopy; FTIR, Thermo Scientific, Nicolet 6700, USA), 표면 성분 분석은 에너지 분산형 엑스선 분광기가 장착된 주사전자현미경(energy-dispersive x-ray spectroscopy/scanning electron microscope, SEM/EDS; JEOL, JSM-7800 Prime, Japan)을 통해 분석하였고, 준설 퇴적물 표면 의 비표면적, 기공의 크기 및 분포 변화는 Brunauer-EmmettTeller (BET, Microtrac MRB, BELSORP-28SA, Japan)법을 이
용하여 분석하였다. 또한 준설 퇴적물 내 유기탄소의 총량과 열분해 과정에서 발생하는 탄화물질(carbonaceous matter)의 총량을 측정하기 위해 총 유기 탄소 분석기(total organic carbon analyzer; TOC Analyzer, Shimadzu, TOC-V-CPH, Japan)를 사 용하였다. 탄화물질은 Grossman 등22)이 제안한 토양 및 퇴적물 Black Carbon 함량 분석법에 따라 준설 퇴적물 내의 천연 유기 물(natural organic carbon)과 무기 탄소(inorganic carbon) 성분 을 제거하고, 잔류하는 유기탄소를 TOC Analyzer로 측정하는 방법을 사용하였다. 이 분석법의 주요 과정은 다음과 같다. 준설 퇴적물을 $50 \mathrm{ml}$ 병에 $200 \mathrm{mg}$ 넣은 다음 $0.1 \mathrm{M}$ 의 $\mathrm{K}_{2} \mathrm{Cr}_{2} \mathrm{O}_{7}$ $5 \mathrm{ml}$ 를 주입한다. 준비된 병을 $60^{\circ} \mathrm{C}$ 항온조에 30 분 동안 넣어 산화반응을 유도한 다음 항온조에서 꺼내어 물 $10 \mathrm{ml}$ 를 주입한 후 4,000 rpm, 20 분 동안 원심분리를 하고 상등액을 버린다. 이후 메탄올과 탈이온수로 세척한 후 24 시간 동안 $105^{\circ} \mathrm{C}$ 오븐 에서 건조하고 $\mathrm{TOC}$ 를 측정한다.

\section{3. 결과 및 고찰}

\section{1. 준설 퇴적물 내 TPH 분석}

열분해 후 준설 퇴적물 내 TPH 함량 분석결과를 Table1에 나타내었다.

Sheehan, Choi 등 ${ }^{8,21)}$ 은 열분해 시 더 높은 온도와 더 긴 체 류시간을 가질수록 $\mathrm{TPH}$ 제거 효율이 증가한다는 것을 입증했 으며 $\mathrm{O}^{\prime} \mathrm{Brien}$ 등 $^{12)}$ 은 열분해 온도가 $400^{\circ} \mathrm{C}$ 이상일 때 $\mathrm{TPH}$ 제거율이 $99 \%$ 이상 도달한다는 것을 관찰하였다. 이처럼 열 분해에 의한 $\mathrm{TPH}$ 정화 효율은 $400{ }^{\circ} \mathrm{C}$ 전후에 도달할 때까지 온도에 따라 증가하는 것이 여러 문헌에 밝혀져 있다. ${ }^{5,16}$ 따라 서 해양 퇴적물을 오염시킬 가능성이 높은 비교적 고분자 계 열의 유류물질인 No. 6 Fuel Oil이 준설 퇴적물에 고농도로 존재할 때 토양오염우려기준인 ${ }^{23)} 500 \mathrm{mg} / \mathrm{kg}$ 미만(1지역 기 준)으로 $\mathrm{TPH}$ 농도를 저감하기 위해서는 안정적인 처리가 가 능한 온도인 $500^{\circ} \mathrm{C}$ 수준으로 열분해하는 것이 적절할 것으로 판단된다. 본 연구의 실험결과를 통해 이러한 판단을 다시 한 번 입증할 수 있었는데, $500^{\circ} \mathrm{C}$ 에서는 $5,000 ~ 50,000 \mathrm{mg} / \mathrm{kg}$ $\mathrm{TPH}$ 조건에서 모두 정량한계 미만으로 $\mathrm{TPH}$ 농도를 저감시킨 반면, 열분해 온도가 정화효율의 큰 영향인자로 작용하는 온도 범위인 $300^{\circ} \mathrm{C}$ 에서는 초기농도가 $20,000 \mathrm{mg} / \mathrm{kg}, 50,000 \mathrm{mg} / \mathrm{kg}$

Table 1. Total petroleum hydrocarbon (TPH) concentrations in sediment before and after pyrolytic treatment.

\begin{tabular}{ccc} 
Initial concentration & \multicolumn{1}{c}{ Residual concentration after pyrolytic treatment } \\
(nominal) & $300^{\circ} \mathrm{C}$ & $500^{\circ} \mathrm{C}$ \\
$5,000 \mathrm{mg} / \mathrm{kg}$ & $234 \mathrm{mg} / \mathrm{kg}$ & $<50 \mathrm{mg} / \mathrm{kg}^{1}$ \\
\hline $20,000 \mathrm{mg} / \mathrm{kg}$ & $2,347 \mathrm{mg} / \mathrm{kg}$ & $<50 \mathrm{mg} / \mathrm{kg}$ \\
\hline $50,000 \mathrm{mg} / \mathrm{kg}$ & $846 \mathrm{mg} / \mathrm{kg}$ & $<50 \mathrm{mg} / \mathrm{kg}$
\end{tabular}

\footnotetext{
${ }^{1}$ Limit of quantification.
} 
일 때 정화토가 토양오염우려기준을 만족하지 못하는 것을 확인하였다. Vidonish 등ํ)에 따르면 유류로 오염된 토양 정화 $350-550^{\circ} \mathrm{C}$ 의 온도 범위에서 열분해가 주요한 열처리 기작이 며 $400-500^{\circ} \mathrm{C}$ 에서 탄화물질이 주로 형성된다. 특히, 열분해 온도가 증가함에 따라 탄화물질의 형성이 증가한다고 알려져 있다. ${ }^{24)}$ 따라서, 추후 실험에서는 효과적으로 준설 퇴적물 내 유류를 제거할 수 있고 탄화물질 형성에 전구물질로 사용되는 $\mathrm{TPH}$ 의 농도가 가장 높은 $50,000 \mathrm{mg} / \mathrm{kg}$ 으로 오염된 준설 퇴적물 을 $500^{\circ} \mathrm{C}$ 에서 열분해 후, 중금속 및 유기오염물질 흡착 실험에 사용되는 대표 열분해 준설 퇴적물(Pyrolyzed Sediment)로 사용 하였다.

\section{2. 열분해에 따른 퇴적물의 중금속 흡착능 변화}

대조군인 Clean Sediment와 실험군인 Pyrolyzed Sediment 의 8 가지 중금속 $(\mathrm{Cd}, \mathrm{Cu}, \mathrm{Pb}, \mathrm{Zn}, \mathrm{Ni}, \mathrm{Hg}, \mathrm{As}, \mathrm{Cr})$ 에 대한 흡착 능 $(200 \mathrm{~g} / 1$ 또는 $20 \mathrm{~g} / 1$ 투여량 조건에서의 액상 농도 저감율) 을 Table 2에 나타내었다.

$\mathrm{Cu}, \mathrm{Zn}$ 와 $\mathrm{Pb}$ 의 경우 Clean Sediment와 Pyrolyzed Sediment 의 흡착능이 서로 통계학적으로 유의한 차이(Student's t test; $p<0.05$ for $\mathrm{Cu}$ and $\mathrm{Pb} ; p<0.001$ for $\mathrm{Zn}$ )를 보였으나, 세 중금 속에 대한 두 준설 퇴적물의 평균 흡착능이 $98 \%$ 이상으로 둘 모두 높은 흡착능을 보였다. Ni에 대한 Clean Sediment의 흡착능은 99.4\%, Pyrolyzed Sediment의 흡착능은 67.7\%로 Clean Sediment의 흡착능이 Pyrolyzed Sediment의 흡착능 보다 $31 \%$ 이상 높았다 $(p<0.05) . \mathrm{Cd}$ 의 경우에도 Clean Sediment의 흡착능이 Pyrolyzed Sediment 보다 약 24\% 높았 으며 통계적인 유의한 차이 $(p<0.001)$ 를 보였다. 반면, $\mathrm{Hg}$ 의 경우 Clean Sediment와 Pyrolyzed Sediment의 흡착능에 통계 적으로 유의한 차이가 없는 것으로 분석되었다 $(p=0.77)$. As 와 $\mathrm{Cr}$ 은 초기 액상 농도와 흡착 실험 후 액상 농도가 통계적으 로 유의한 차이를 나타내지 않았다. 이는 Clean Sediment와 Pyrolyzed Sediment 모두 이 두 중금속류에 대한 흡착능이 다 른 중금속류에 대한 흡착능에 비해 현저히 낮다는 것을 의미 한다. Cheng 등 ${ }^{11}$ 의 연구에 따르면 흡착 실험 시 고액비에 따라 중금속의 흡착능이 달라질 수 있다고 보고하고 있다. 본 논문에서 생산된 열분해 준설토를 이용하여 중금속 흡착 실험 시에도 고액비(예: 1:5 또는 1:50)를 달리한다면 각 중금속별

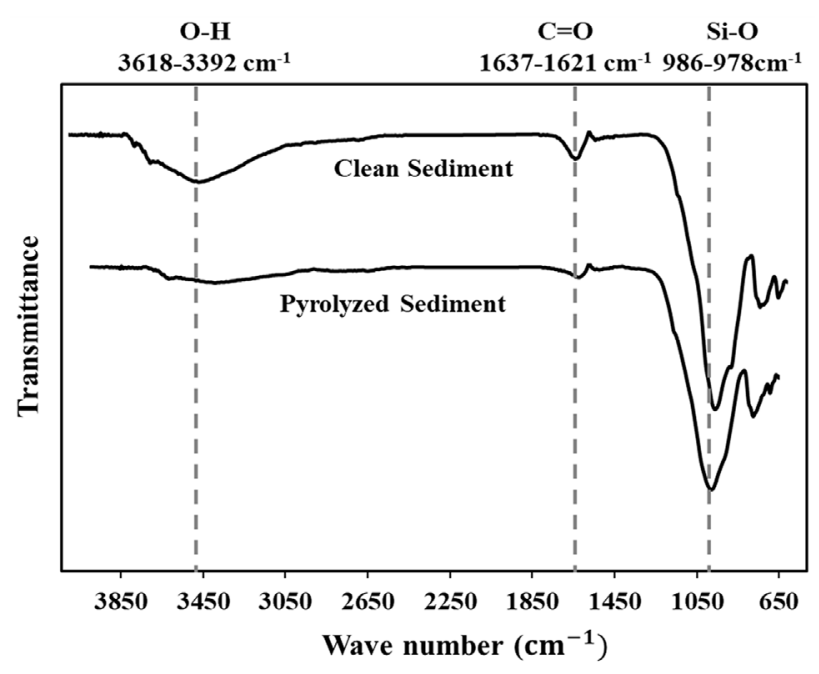

Fig.2. FTIR spectra of clean sediment and pyrolyzed sediment.

흡착능 결과 또한 달라질 수 있을 것으로 사료된다. 하지만, 중금속의 경우 Pyrolyzed sediment가 Clean sediment의 흡착 능과 비교하여 큰 차이가 없거나 오히려 감소하는 것으로 분 석되었다. 따라서, 중금속을 대상으로 고액비를 달리하여 흡 착 실험을 수행하더라도 열분해 전후 중금속의 흡착능에 대한 전반적인 경향성은 크게 달라지지 않을 것으로 사료된다.

열분해 이후 중금속 흡착능 저감 원인을 알아보기 위해 정 화 전후 준설 퇴적물을 대상으로 중금속 흡착능에 영향을 미 치는 작용기(functional group)와 준설 퇴적물의 물리화학적 특성변화를 분석하였다. 첫 번째로 FTIR 분석을 통해 열분해 전후 준설 퇴적물의 작용기를 분석한 뒤 그 결과를 Fig.2에 나타내었다.

FTIR 분석 결과, O-H Hydroxyl Groups (Clean Sediment $=$ $3,393 \mathrm{~cm}^{-1}$, Pyrolyzed Sediment $=3,619 \mathrm{~cm}^{-1}$ ), $\mathrm{C}=\mathrm{O}$ Carbonyl Groups $\left(\right.$ Clean Sediment $=1,638 \mathrm{~cm}^{-1}$, Pyrolyzed Sediment $=$ $1,622 \mathrm{~cm}^{-1}$ ) 그리고 $\mathrm{Si}-\mathrm{O}$ (Clean Sediment $=986 \mathrm{~cm}^{-1}$, Pyrolyzed Sediment $\left.=979 \mathrm{~cm}^{-1}\right)$ 가 주요한 작용기로 분석되었 다. 열분해 후 산소와 -OH를 포함한 작용기가 감소하였으며, 이는 열분해 과정에서 일어난 탈수(dehydration)와 탈산소 (deoxygenation) 반응이 원인이 된 것으로 사료된다. ${ }^{25)}$ 이러 한 작용기의 변화는 준설 퇴적물 내 중금속 흡착 매커니즘에 영향을 미쳐 중금속 흡착능 감소에 원인이 될 수 있다. 토양이

Table 2. Heavy metal removal efficiency by clean and pyrolyzed sediment in aqueous solutions at a solid to liquid ratio of 200 $\mathrm{g} / \mathrm{l}(\mathrm{Cd}, \mathrm{Cu}, \mathrm{Pb}, \mathrm{Zn}, \mathrm{Ni}, \mathrm{Hg})$ and $20 \mathrm{~g} / \mathrm{l}(\mathrm{As}, \mathrm{Cr}, \mathrm{Hg})$. Data are presented as mean \pm standard deviation of triplication measurements.

\begin{tabular}{|c|c|c|c|c|c|c|c|c|}
\hline \multirow{2}{*}{ Sediment } & \multicolumn{8}{|c|}{ Removal efficiency (\%) } \\
\hline & $\mathrm{Ni}$ & $\mathrm{Cu}$ & $\mathrm{Zn}$ & $\mathrm{Cd}$ & $\mathrm{Pb}$ & $\mathrm{Hg}$ & As & $\mathrm{Cr}$ \\
\hline Clean & $99.38 \pm 0.02$ & $99.96 \pm 0.00$ & $99.88 \pm 0.02$ & $99.36 \pm 0.05$ & $99.99 \pm 0.00$ & $40.99 \pm 3.60$ & $N A *$ & $N A$ * \\
\hline Pyrolysis & $67.66 \pm 3.77$ & $99.74 \pm 0.05$ & $98.44 \pm 0.05$ & $75.12 \pm 0.42$ & $99.99 \pm 0.00$ & $42.33 \pm 0.59$ & $N A *$ & $N A *$ \\
\hline
\end{tabular}

* Not available. The data are not statistically significantly different from the initial aqueous concentration (student's t test; as in clean sediment: $p=0.51$, as in pyrolyzed sediment: $p=0.22, \mathrm{Cr}$ in clean sediment: $p=0.35, \mathrm{Cr}$ in pyrolyzed sediment: $p=0.87$ ). 
Table 3. Physicochemical properties of clean sediment and pyrolyzed sediment.

\begin{tabular}{ccccccc} 
Sediment & $\begin{array}{c}\text { Total organic carbon } \\
(\%)\end{array}$ & $\begin{array}{c}\text { Black carbon } \\
(\%)\end{array}$ & $\begin{array}{c}\text { BET-N } \mathrm{N}_{2} \text { surface area } \\
\left(\mathrm{m}^{2} / \mathrm{g}\right)\end{array}$ & $\begin{array}{c}\text { Total pore volume } \\
\left(\mathrm{cm}^{3} \mathrm{~g}^{-1}\right)\end{array}$ & $\begin{array}{c}\text { Average pore diameter } \\
(\mathrm{nm})\end{array}$ \\
\hline Clean & $0.69 \pm 0.00$ & $0.09 \pm 0.00$ & $12.12 \pm 0.52$ & $0.03 \pm 0.00$ & $10.95 \pm 0.12$ \\
\hline Pyrolysis & $1.48 \pm 0.02$ & $0.26 \pm 0.01$ & $8.76 \pm 0.35$ & $0.04 \pm 0.00$ & $20.34 \pm 1.15$ \\
\hline
\end{tabular}

(a)

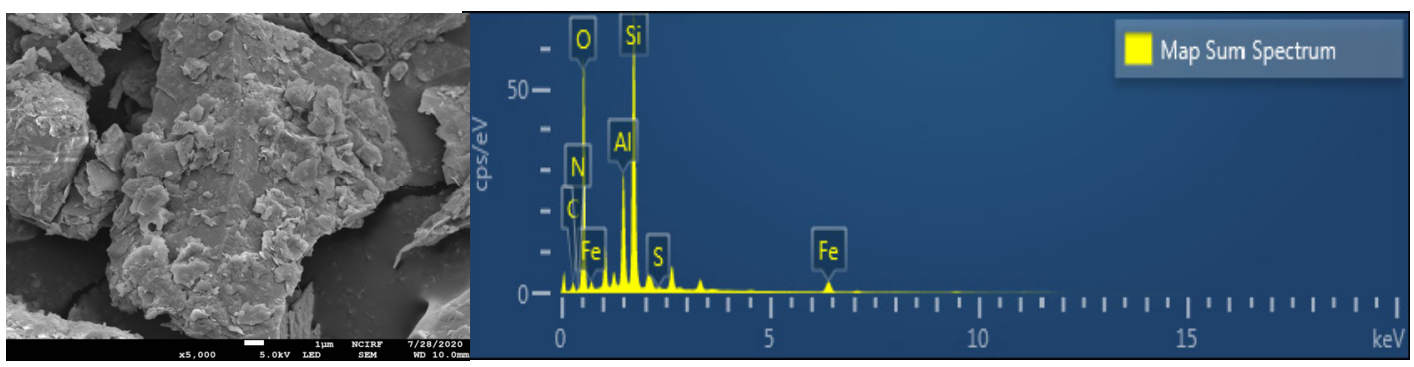

(b)

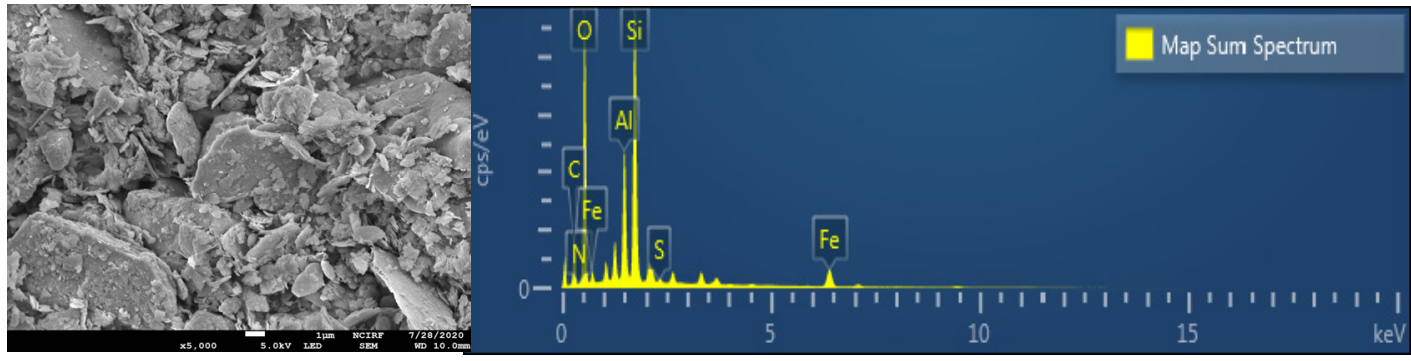

Fig. 3. SEM image (left) and EDS spectrum (right) of (a) clean sediment and (b) pyrolyzed sediment.

중금속을 흡착하는 매커니즘에는 양이온 교환(cation exchange), 착물화(complexation), 정전기 인력(electrostatic attraction), $\pi$ 결합 등이 있으며, 그 중 산소를 포함하는 작용기와 중금속 간의 배위결합을 의미하는 금속 착화(metal complexation)는 흡착 매커니즘에서 중요한 역할을 한다. ${ }^{15)}$ 열분해로 산소를 포함한 작용기가 감소함으로써 중금속과의 배위결합이 감소 한 것이 일부 중금속의 흡착능 감소에 영향을 미친 것으로 사료된다. Wang 등 ${ }^{26}$ 의 연구에서도 우분을 열분해 후 산소를 포함하는 작용기가 감소함에 따라 열분해 전에 비해 $\mathrm{Cd}$ 과 $\mathrm{Ni}$ 의 흡착능이 감소하는 결과를 보였다. Table3에 나타낸 준설 퇴적물의 $\mathrm{BET}$ 측정 결과, 열분해 이후 비표면적이 $28 \%$ 감소 한 것으로 분석되었다.

$\mathrm{Kim}$ 등 $^{1)}$ 에 따르면 열처리 과정에서 준설 퇴적물 내 점토와 실 트와 같은 미세토 크기의 입자가 입자응집(particle aggregation) 을 통해 모래 크기의 입자가 증가한다고 주장하였다. 본 연구 에서 열분해에 따라 준설토의 비표면적이 감소한 것 역시 열 처리 과정에서의 퇴적물 입자응집 현상에 의한 것으로 볼 수 있으며, 이러한 비표면적 감소 또한 중금속 흡착능 감소에 기 여했을 것으로 판단된다. 미세토에는 양이온 중금속의 흡착 site가 되는 음전하 표면이 많이 분포하며, $\mathrm{BET}$ 측정으로 확인 한 준설 퇴적물의 비표면적 저감분은 양이온 중금속 흡착에 주된 기여를 하는 표면일 가능성이 높다.
$\mathrm{Cr}$ 과 $\mathrm{As}$ 는 다른 중금속류와 달리 산소음이온(oxyanion) 형 태로 존재하며, 본 연구에서는 중금속 오염수의 $\mathrm{pH}$ 를 5.0 이 되도록 보정하였으므로 $\mathrm{HCrO}_{4}^{-}$와 $\mathrm{H}_{2} \mathrm{AsO}_{4}{ }^{-}$형태로 존재하는 중금속이온을 흡착 실험에 사용하였다. 양이온 중금속 $(\mathrm{Cd}$, $\mathrm{Cu}, \mathrm{Pb}, \mathrm{Zn}, \mathrm{Ni}, \mathrm{Hg}$ )은 표면에 음전하를 띤 준설 퇴적물 내 점토와 정전기적 인력 또는 리간드 결합을 통해 잘 흡착되지 만, 수용액 상태에서 음이온 형태로 존재하는 $\mathrm{Cr}$ 과 As의 경우 점토와 같은 전하를 띠고 있기 때문에 반발력이 발생하여 표 면 흡착이 잘 일어나지 않을 수 있다. Wang, Mishra 등 ${ }^{27,28)}$ 은 철 산화물, 망간 산화물, 알루미늄 산화물, 규산질 점토광물 등이 음이온 중금속에 흡착 효과가 있다고 주장했으며, Bengtsson 등 ${ }^{29)}$ 은 수은 흡착에서도 이러한 산화물 및 광물이 주요한 역할을 한다는 것을 입증하였다. Fig.3과 Table4에 나타낸 SEM/EDS를 이용한 원소비율(atomic ratio) 분석을 통 해 열분해 후 준설 퇴적물 표면에 탄소 비율이 2.24배 증가한 것을 확인하였다. 이는 열분해 과정에서 준설토 표면에 형성 된 탄화물질이 철, 알루미늄, 규소의 광물 표면을 덮어 $\mathrm{Cr}$ 과 $\mathrm{As}$ 의 흡착 site가 감소된 것으로 사료된다. 따라서, 열분해 시 입자응집과 탄화물질 형성이 표면에 존재하는 광물의 흡착 site를 감소시킴에 따라 $\mathrm{As}$ 와 $\mathrm{Cr}$ 의 흡착 증대에 긍정적인 영향 을 미치지 못한 것으로 사료된다. 
Table 4. Elemental compositions of clean sediment and pyrolyzed sediment surface determined by SEM/EDS.

\begin{tabular}{|c|c|c|c|c|c|c|}
\hline \multirow{2}{*}{ Sediment } & \multicolumn{6}{|c|}{ Elemental composition (\%) } \\
\hline & C & 0 & $\mathrm{~N}$ & $\mathrm{Si}$ & $\mathrm{Al}$ & $\mathrm{Fe}$ \\
\hline Clean & 15.76 & 60.32 & 1.44 & 14.32 & 5.96 & 2.1 \\
\hline Pyrolysis & 35.42 & 49.48 & 0.5 & 8.22 & 4.17 & 2.05 \\
\hline
\end{tabular}

Table 5. Logarithms of sediment-water distribution coefficients ( $\log K_{d}$ ) and sediment organic carbon-water distribution coefficients $\left(\log K_{o c}\right)$ determined in the current study for bisphenol $A$ and phenanthrene. Log $K_{o c}$ values for sediment from the literature are provided for comparison.

\begin{tabular}{|c|c|c|c|c|}
\hline & & Source & $\mathrm{K}_{\mathrm{d}}$ & Log $K_{\text {oc }}$ \\
\hline \multirow{9}{*}{ Bisphenol A } & \multirow{2}{*}{ This study } & Clean sediment & $2.06 \pm 0.11$ & $2.49 \pm 0.19$ \\
\hline & & Pyrolyzed sediment & $31.16 \pm 0.62$ & $3.32 \pm 0.49$ \\
\hline & \multirow{7}{*}{ Reference } & EPI Suite ${ }^{\mathrm{TM}} \mathrm{v} 4.11$ & - & 3.18 \\
\hline & & Styszko $2016^{37)}$ & - & $3.30-3.60$ \\
\hline & & Campbell, Borglin et al. 2006 & - & $2.50-3.18$ \\
\hline & & Huang, Liu et al. 201739) & - & 3.18 \\
\hline & & Salgueiro-González, Castiglioni et al. 2018 ${ }^{40)}$ & - & 3.60 \\
\hline & & Wu, Zhang et al. 201841) & - & 3.80 \\
\hline & & Xu, Wang et al. 2008 ${ }^{42)}$ & - & 2.65 \\
\hline \multirow{11}{*}{ Phenanthrene } & \multirow{2}{*}{ This study } & Clean Sediment & $12.44 \pm 5.68$ & $3.26 \pm 2.91$ \\
\hline & & Pyrolyzed Sediment & $92.68 \pm 15.40$ & $3.80 \pm 3.02$ \\
\hline & \multirow{9}{*}{ Reference } & EPI Suite ${ }^{T M}$ v4.11 & - & 4.35 \\
\hline & & Bonin, Simpson 200743) & - & 3.69 \\
\hline & & Karickhoff $1981^{44)}$ & - & 4.08 \\
\hline & & Simpson, Chefetz et al. 200345) & - & 4.43 \\
\hline & & Shchegolikhina, Kunhi Mouvenchery et al. 2014 46 ) & - & 4.12 \\
\hline & & Zhang, Wang 201147) & - & 4.15 \\
\hline & & Yang, Wang et al. 201148) & - & 4.36 \\
\hline & & Song, Qiang et al. 2016 49 ) & - & 4.22 \\
\hline & & Yu, Xu et al. 200950) & - & $3.66-4.62$ \\
\hline
\end{tabular}

\section{3. 열분해에 따른 퇴적물의 유기오염물질 흡착능 변화}

유기오염물질에 대한 준설 퇴적물의 흡착능 평가결과는

Table 5에 나타내었다.

Bisphenol A에 대한 $\mathrm{K}_{\mathrm{oc}}$ 값은 Clean Sediment에 비해 Pyrolyzed Sediment가 약 6.75배 정도 높았으며, phenanthrene의 $\mathrm{K}_{\mathrm{oc}}$ 값 역시 Pyrolyzed Sediment가 Clean Sediment에 비해 3.47배 더 높았다. Bisphenol A와 phenanthrene에 대한 토양 분배 계수 $\mathrm{K}_{\mathrm{d}}$ 값 또한 Pyrolyzed Sediment가 Clean Sediment보다 각각 15.1 배 및 7.45배 높았다. 흡착 특성 변화는 FTIR과 유기물 함량 분석으로 확인한 각 준설 퇴적물의 물리화학적 특성과 연관지어 설명할 수 있다. Fig.2에 제시된 FTIR결과에서 열분 해 후 $-\mathrm{OH}$ 와 $\mathrm{C}=\mathrm{O}$ 작용기가 감소함에 따라 수소결합과 $\pi-\pi-$ 전자-공여체-수용체 상호작용 $(\pi-\pi$-electron-donor acceptor interaction)에 의한 Bisphenol A와 Phenanthrene의 흡착능이 감소했을 것으로 사료된다. ${ }^{30,31)}$ 하지만, 열분해 후 두 유기오 염물질의 $\mathrm{K}_{\mathrm{oc}}$ 값이 증가된 것으로 보아 열분해 과정에서 생성
된 탄화물질이 두 유기오염물질 흡착능 증가에 주요한 역할을 한 것으로 사료된다. Table 3의 결과와 같이 TOC와 black carbon의 함량이 열분해 후 각각 2.14 배, 2.89 배 증가되었다. 앞서 언급된 것과 같이 열분해를 이용해 유류 오염 준설 퇴적 물의 정화 효율과 Pyrolyzed Sediment의 유무기 오염물질에 대한 흡착특성을 알아보기 위해 해양 준설 퇴적물에서 빈번히 발견되는 유류 오염물질인 No. 6 Fuel Oil을 Clean Sediment 에 인공오염시킨 후 열분해 정화를 적용하였다. No. 6 Fuel Oil로 오염된 준설 퇴적물 내 $\mathrm{TPH}$ 농도가 $50,000 \mathrm{mg} / \mathrm{kg}$ 으로 상당히 높았음에도 불구하고 열분해 후 $\mathrm{TPH}$ 농도가 정량한계 $(<50 \mathrm{mg} / \mathrm{kg})$ 수준으로 낮아졌다. 이 과정에서 No. 6 Fuel Oil 이 전구물질로 사용되어 탄화물질이 형성됨에 따라 Pyrolyzed sediment가 clean sediment에 비해 TOC와 black carbon의 양 이 증가된 것으로 사료된다. Uchimiya 등 $^{32}$ 의 연구에서는 열 분해 시 휘발성 유기 화합물(volatile organic compounds, VOC) 이 휘발되고 고정탄소가 증가하는 탄화(carbonization) 과정을 
통해 탄화물질이 증가할 수 있음을 입증하였다. Table 4의 $\mathrm{SEM} / \mathrm{EDS}$ 의 결과에서도 Pyrolyzed Sediment가 Clean Sediment 에 비해 표면의 탄소비율이 2.24배 증가하였으며, Vidonish 등 ${ }^{11)}$ 의 연구에서도 유류오염 토양을 열분해 정화 후 토양 표면에 필름형태의 탄화물질이 형성됨이 확인되었다. Dong 등 ${ }^{15)}$ 에 따르면 유기물이 많이 함유된 준설 퇴적물 열분해 시 수소와 산소가 감소하고 탄소가 증가함에 따라 $\mathrm{H} / \mathrm{C}$ 와 $\mathrm{O} / \mathrm{C}$ 비율이 감소함에 따라 열분해 준설 퇴적물이 방향족성(aromaticity)이 증가되고 극성(polarity)이 감소한다고 주장하였다. 따라서, 본 연구에서 열분해를 통해 정화된 준설 퇴적물 또한 방향족성이 증가하고 극성이 감소함에 따라 열분해 후 극성이 낮은 방향 족 화합물 bisphenol A, phenanthrene의 흡착능이 향상된 것으 로 사료된다. 마찬가지로 열분해 후 $\mathrm{K}_{\mathrm{d}}$ 값 증가 또한 $\mathrm{K}_{\mathrm{d}}=\mathrm{f}_{\mathrm{oc}}$ $\times \mathrm{K}_{\mathrm{oc}}$ 관계식에 따라 열분해 후 유기탄소 함량인 $\mathrm{f}_{\mathrm{oc}}$ 의 증가와 $\mathrm{K}_{\mathrm{oc}}$ 값의 증가로 설명할 수 있다. Hydrophobic effect 외에도 퇴적물 내 유기오염물질 흡착 메커니즘에는 electrostatic attraction, cation exchange, pore-filling effect, $\pi-\pi$ interactions 등이 있다. Wang 등 ${ }^{52)}$ 에 따르면 bisphenol의 $-\mathrm{OH}$ 작용기와 탄화물의 $-\mathrm{O}$ 작용기 사이의 $-\mathrm{H}$ 결합효과로 인해 흡착능 증 가에 영향을 미친다고 알려져 있다. 따라서 bisphenol과 phenanthrene의 분자 구조를 살펴봤을 때 phenanthrene과 달 리 작용기가 있는 bisphenol A에서 hydrophobic effect와 함께 $\pi-\pi$ interactions과 같은 다른 흡착 메커니즘의 영향을 받아 bisphenol $\mathrm{A}$ 의 $\mathrm{K}_{\mathrm{oc}}$ 증가비가 더 높은 것으로 사료된다.

실험에서 사용된 유기오염물질들을 물질의 환경 거동, 분배, 물성, 독성 등을 예측하는 프로그램인 Estimation Programs Interface Suite, U.S. Environmental Protection Agency (EPI Suite $\left.^{\mathrm{TM}} \mathrm{v} 4.11\right)$ 와 여러 문헌값을 통해 얻은 퇴적물의 $\mathrm{K}_{\mathrm{oc}}$ 값을 본 연구의 결과와 비교하였다. Clean Sediment의 경우 bisphnol $\mathrm{A}$ 와 phenanthrene 두 물질 모두 일반 토양보다 $\mathrm{K}_{\mathrm{oc}}$ 값이 현저 히 낮았는데, 유류오염-열분해 과정을 통해 그 값이 크게 증가 하여 문헌값 범위 내로 진입하였다. Bisphenol A는 산업계에 서 플라스틱 제조의 원료로 사용되며 ${ }^{33)}$, phenanthrene은 살 충제, 계면활성제 및 일부 의약품을 제조하는데 사용된다. ${ }^{34)}$ 이러한 물질을 제조하는 산업체 주변에는 bisphenol A나 phenanthrene와 같은 오염물질의 유입이 증가하게 되고 유입 된 오염물질은 쉽게 분해되지 않고 생물농축을 일으켜 발암, 돌연변이, 면역체계 교란, 중추신경계 손상 등을 초래한다. ${ }^{35)}$ 따라서 인체에 미치는 악영향을 막고 환경영향을 줄이기 위해 산업체 주변에 있는 오염물질을 제거하려는 노력이 필요하며, 오염원 주변에 유기오염물질에 대한 이동성 저감(retardation) 능력이 향상된 준설 퇴적물을 성토재, 복토재 등으로 사용한 다면 오염물질 확산으로 인한 주변환경 오염 피해를 저감할 수 있는 좋은 해결방안이 될 것이다. 이러한 준설 퇴적물 관리 방법은 준설 퇴적물을 단순히 매립, 투기하는 현재의 일차원 적인 방법에서 벗어나 이를 유용한 자원으로 활용함으로써
경제적·환경적 편익을 획득하는 효과적인 방법이 될 것으로 기대된다.

\section{4. 결 론}

본 연구에서는 유류로 오염된 준설 퇴적물을 열분해를 이용 하여 오염물질을 완전히 제거한 후 처리된 준설 퇴적물의 중 금속 $(\mathrm{Ni}, \mathrm{Cu}, \mathrm{Zn}, \mathrm{Cd}, \mathrm{Pb}, \mathrm{Hg}, \mathrm{As}, \mathrm{Cr}$ )과 유기오염물질 (bisphenol A, phenanthrene)의 흡착 특성을 평가함으로써 처 리 준설 퇴적물의 적절한 유효활용 방안에 대해 고찰하였다. 또한 열분해에 의한 중금속과 유기오염물질의 흡착 특성 변화 를 준설 퇴적물의 물리화학적 특성 변화와 연계하여 분석하였 다. 깨끗한 준설 퇴적물과 유류오염 후 열분해 정화된 퇴적물 의 중금속 흡착능 차이를 분석한 결과, $\mathrm{Cu}, \mathrm{Zn}, \mathrm{Pb}$ 는 두 준설 토 모두 $200 \mathrm{~g} / 1$ 의 고액비 조건에서 $98 \%$ 이상의 높은 용존 중금속 제거효율을 나타냈으나, $\mathrm{Ni}$ 과 $\mathrm{Cd}$ 는 열분해 후 제거효 율이 상당 수준 감소하였다. 이는 열분해 과정에서 퇴적물 내의 산소 포함 작용기가 감소하여 중금속과의 배위결합 site 가 줄어들고, 퇴적물의 비표면적이 감소하여 노출된 흡착 site 가 감소한 데에 기인한 것으로 사료된다. 유기오염물질인 bisphenol A와 phenanthrene의 경우 열분해 후 준설 퇴적물의 흡착능이 크게 향상되었다. 열분해 후 준설 퇴적물의 비표면 적과 극성 작용기가 감소한 반면, 유기물질에 대해 높은 흡착 능을 갖는 탄화물질 함량이 크게 증가한 것이 흡착능 증가의 주요 원인인 것으로 사료된다. 유류오염 준설 퇴적물을 열분 해 처리로 정화하여 생산한 정화 준설 퇴적물은 높은 유기오 염물질 흡착능을 지니므로, 유기화학물질로 인한 화학사고가 우려되는 지역이나 유기화학공업단지의 토양 개량제 또는 복 토재, 유기오염물질로 오염된 퇴적물의 원위치 피복(in-situ capping) 매질 등에 활용되어 오염물질의 생물학적 이용성과 확산을 저감하고, 그 인체 건강과 환경에 대한 악영향을 방지 하는데 기여할 수 있을 것이라 기대된다.

\section{Acknowledgment}

본 연구는 한국연구재단의 연구비 지원으로 수행되었습니다 (과제번호: 2018R1A1A1A05020659). 이에 감사드립니다.

\section{References}

1. K. Kim, H. Kwon, G. Joo, Y. Choi, Development of a low-temperature thermal treatment process for the production of plant-growable media using petroleum-impacted dredged sediment, Sci. Total. Environ., 776, 145917(2021).

2. K. Kim, K. Nam, W. Kang, Y. Choi, Decision making framework for beneficial use of dredged sediment in the terrestrial environment based on environmental risk 
assessment and sediment characterization, J. Korean Soc. Environ. Eng., 40(6), 227-238(2018).

3. P. Verlaan, Current legal developments london convention and london protocol, Int. J. Mar. Coast. Law., 26(1), 185-194(2011).

4. J. Y. Choi, K. R. Kim, E. J. Won, Use of the remediation technology of contaminated dredged sediments for beneficial use of dredged marine sediments, J. Rec. Const. Resources, 11(4), 53-58(2016).

5. D.-C. Li, W.-F. Xu, Y. Mu, H.-Q. Yu, H. Jiang, J. C. Crittenden, Remediation of petroleum-contaminated soil and simultaneous recovery of oil by fast pyrolysis, Environ. Sci. Technol., 52(9), 5330-5338(2018).

6. A. A. Odetayo, D. D. Reible, D. Acevedo-Mackey, C. Price, L. Thai, Application of polyoxymethylene passive air sampler to monitor hydrophobic organics in air around a confined disposal facility, Chemosphere, 263, 127827(2021).

7. J. Gebert, C. Knoblauch, A. Gröngröft, Gas production from dredged sediment, Waste Manage., 85, 82-89(2019).

8. C. Sheehan, J. Harrington, Management of dredge material in the Republic of Ireland - a review, Waste Manage., 32(5), 1031-1044(2012).

9. M. W. Lim, E. V. Lau, P. E. Poh, A comprehensive guide of remediation technologies for oil contaminated soil-present works and future directions, Mar. Pollut. Bull., 109(1), 14-45(2016).

10. C. Zhao, Y. Dong, Y. Feng, Y. Li, Y. Dong, Thermal desorption for remediation of contaminated soil: a review, Chemosphere, 221, 841-855(2019).

11. J. E. Vidonish, K. Zygourakis, C. A. Masiello, X. Gao, J. Mathieu, P. J. Alvarez, Pyrolytic treatment and fertility enhancement of soils contaminated with heavy hydrocarbons, Environ. Sci. Technol., 50(5), 2498-2506(2016).

12. P. L. O'Brien, T. M. DeSutter, F. X. M. Casey, E. Khan, A. F. Wick, Thermal remediation alters soil properties - a review, J. Environ. Manage., 206, 826-835(2018).

13. K. Kim, S. Yoon, H. Kwon, Y. Choi, Effects of treatment agents during acid washing and $\mathrm{pH}$ neutralization on the fertility of heavy metal-impacted dredged marine sediment as plant-growing soil, Environ. Pollut., 267, 115466(2020).

14. B. Pan, P. Huang, M. Wu, Z. Wang, P. Wang, X. Jiao, B. Xing, Physicochemical and sorption properties of thermally-treated sediments with high organic matter content, Bioresour. Technol., 103(1), 367-373(2012).

15. X. Dong, C. Wang, H. Li, M. Wu, S. Liao, D. Zhang, B. Pan, The sorption of heavy metals on thermally treated sediments with high organic matter content, Bioresour. Technol., 160, 123-128(2014).

16. J. E. Vidonish, P. J. J. Alvarez, K. Zygourakis, Pyrolytic remediation of oil-contaminated soils: reaction mechanisms, soil changes, and implications for treated soil fertility, Ind. Eng. Chem. Res., 57(10), 3489-3500(2018).

17. M. Wu, B. Pan, D. Zhang, D. Xiao, H. Li, C. Wang, P. Ning, The sorption of organic contaminants on biochars derived from sediments with high organic carbon content, Chemosphere, 90(2), 782-788(2013).
18. M. Ahmad, A. U. Rajapaksha, J. E. Lim, M. Zhang, N. Bolan, D. Mohan, M. Vithanage, S. S. Lee, Y. S. Ok, Biochar as a sorbent for contaminant management in soil and water: a review, Chemosphere, 99, 19-33(2014).

19. Korean Ministry of Environment, Korean standard method for soil analysis, Korean Ministry of Environment, Sejong, Korea, pp.198-209(2018).

20. Y. Choi, Y.-M. Cho, R. G. Luthy, Polyethylene-water partitioning coefficients for parent-and alkylated-polycyclic aromatic hydrocarbons and polychlorinated biphenyls, Environ. Sci. Technol., 47(13), 6943-6950(2013).

21. Y. Choi, Y.-M. Cho, W. R. Gala, R. G. Luthy, Measurement and modeling of activated carbon performance for the sequestration of parent-and alkylated-polycyclic aromatic hydrocarbons in petroleum-impacted sediments, Environ. Sci. Technol., 47(2), 1024-1032(2013).

22. A. Grossman, U. Ghosh, Measurement of activated carbon and other black carbons in sediments, Chemosphere, 75(4), 469-475(2009).

23. Korean Ministry of Environment, Enforcement Regulation of the Soil Environment Conservation Act, Korean Ministry of Environment, Sejong, Korea, pp. 873(2020).

24. G. Chu, J. Zhao, Y. Liu, D. Lang, M. Wu, B. Pan, C. E. W. Steinberg, The relative importance of different carbon structures in biochars to carbamazepine and bisphenol A sorption, J. Hazard. Mater., 373, 106-114(2019).

25. S. Cheng, T. Chen, W. Xu, J. Huang, S. Jiang, B. Yan, Application research of biochar for the remediation of soil heavy metals contamination: a review, Molecules, 25(14), 3167(2020).

26. S. Wang, J.-H. Kwak, M. S. Islam, M. A. Naeth, M. G. El-Din, S. X. Chang, Biochar surface complexation and Ni(II), Cu(II), and $\mathrm{Cd}(\mathrm{II})$ adsorption in aqueous solutions depend on feedstock type, Sci. Total. Environ., 712, 136538(2020).

27. S. Wang, B. Gao, Y. Li, Y. Wan, Creamer, A. E., Sorption of arsenate onto magnetic iron - manganese $(\mathrm{Fe}-\mathrm{Mn})$ biochar composites, RSC Adv., 5(83), 67971-67978(2015).

28. T. Mishra, D. K. Mahato, A comparative study on enhanced arsenic(V) and arsenic(III) removal by iron oxide and manganese oxide pillared clays from ground water, J. Environ. Chem. Eng., 4(1), 1224-1230(2016).

29. G. Bengtsson, F. Picado, Mercury sorption to sediments: dependence on grain size, dissolved organic carbon, and suspended bacteria, Chemosphere, 73(4), 526-531(2008).

30. M. B. Ahmed, J. L. Zhou, H. H. Ngo, M. A. H. Johir, L. Sun, M. Asadullah, D. Belhaj, Sorption of hydrophobic organic contaminants on functionalized biochar: protagonist role of $\pi-\pi$ electron-donor-acceptor interactions and hydrogen bonds, J. Hazard. Mater., 360, 270-278(2018).

31. J. Wang, M. Zhang, Adsorption characteristics and mechanism of bisphenol A by magnetic biochar, Int. J. Environ. Res. Public Health., 17(3), 1075(2020).

32. M. Uchimiya, L. H. Wartelle, K. T. Klasson, C. A. Fortier, I. M. Lima, Influence of pyrolysis temperature on biochar property and function as a heavy metal sorbent in soil, J. Agric. 
Food. Chem., 59(6), 2501-2510(2011)

33. T. Yamamoto, A. Yasuhara, H. Shiraishi, O. Nakasugi, Bisphenol A in hazardous waste landfill leachates, Chemosphere, 42(4), 415-418(2001).

34. C. A. O. Ribeiro, Y. Vollaire, A. Sanchez-Chardi, H. Roche, Bioaccumulation and the effects of organochlorine pesticides, $\mathrm{PAH}$ and heavy metals in the Eel (Anguilla anguilla) at the Camargue Nature Reserve, France, Aquat. Toxicol., 74(1), 53-69(2005).

35. P. Irigaray, D. Belpomme, Basic properties and molecular mechanisms of exogenous chemical carcinogens, Carcinogenesis, 31(2), 135-148(2010).

36. Y. Roh, N. T. Edwards, S. Y. Lee, C. A. Stiles, S. Armes, J. E. Foss, Thermal treated soil for mercury removal: soil and phytotoxicity tests, J. Environ. Qual., 29(2), 415-424(2000).

37. K. Styszko, Sorption of emerging organic micropollutants onto fine sediments in a water supply dam reservoir, J. Soils. Sediments, 16(2), 677-686(2016).

38. C. G. Campbell, S. E. Borglin, F. B. Green, A. Grayson, E. Wozei, W. T. Stringfellow, Biologically directed environmental monitoring, fate, and transport of estrogenic endocrine disrupting compounds in water: a review, Chemosphere, 65(8), 1265-1280(2006).

39. R.-P. Huang, Z.-H. Liu, S.-F. Yuan, H. Yin, Z. Dang, P.-X. $\mathrm{Wu}$, Worldwide human daily intakes of bisphenol A (BPA) estimated from global urinary concentration data (2000-2016) and its risk analysis, Environ. Pollut., 230, 143-152(2017).

40. N. Salgueiro-González, S. Castiglioni, E. Zuccato, I. Turnes-Carou, P. López-Mahía, S. Muniategui-Lorenzo, Recent advances in analytical methods for the determination of 4-alkylphenols and bisphenol A in solid environmental matrices: a critical review, Anal. Chim. Acta, 1024, 39-51(2018)

41. L.-H. Wu, X.-M. Zhang, F. Wang, C.-J. Gao, D. Chen, J. R. Palumbo, Y. Guo, E. Y. Zeng, Occurrence of bisphenol $\mathrm{S}$ in the environment and implications for human exposure: a short review, Sci. Total. Environ., 615, 87-98(2018).

42. X. Xu, Y. Wang, X. Li, Sorption behavior of bisphenol A on marine sediments, J. Environ. Sci. Health A, 43(3), 239-246(2008).

43. J. L. Bonin, M. J. Simpson, Variation in phenanthrene sorption coefficients with soil organic matter fractionation: the result of structure or conformation?, Environ. Sci. Technol., 41(1), 153-159(2007).

44. S. W. Karickhoff, Semi-empirical estimation of sorption of hydrophobic pollutants on natural sediments and soils, Chemosphere, 10(8), 833-846(1981).

45. M. J. Simpson, B. Chefetz, P. G. Hatcher, Phenanthrene sorption to structurally modified humic acids, J. Environ. Qual., 32(5), 1750-1758(2003).

46. A. Shchegolikhina, Y. K. Mouvenchery, S. K. Woche, J. Bachmann, G. E. Schaumann, B. Marschner, Cation treatment and drying temperature effects on nonylphenol and phenanthrene sorption to a sandy soil, J. Plant. Nutr. Soil. Sci., 177(2), 141-149(2014).
47. Y. Zhang, J. Wang, Determination of retardation effect of soil organic matter on aqueous leaching of polycyclic aromatic hydrocarbons, in Preceedings of 2011 International Conference on Computer Distributed Control and Intelligent Environmental Monitoring, IEEE, Changsha, China, pp. 2039-2042(2011).

48. Z. Yang, L. Wang, J. Niu, Sorption mechanisms of coexisting PAHs on sediment organic fractions, Environ. Toxicol. Chem., 30(3), 576-581(2011).

49. C. Song, F. Qiang, L. Tianxiao, L. Dong, L. Yifan, W. Min, Transfer and migration of polycyclic aromatic hydrocarbons in soil irrigated with long-term wastewater, Int. J. Agric. Biol. Eng., 9(5) 83-92(2016).

50. Y. Yu, J. Xu, P. Wang, H. Sun, S. Dai, Sediment-porewater partition of polycyclic aromatic hydrocarbons (PAHs) from Lanzhou Reach of Yellow River, China, J. Hazard. Mater., 165(1-3), 494-500(2009).

51. Q. Cheng, Q. Huang, S. Khan, Y. Liu, Z. Liao, G. Li, Y. S. Ok, Adsorption of $\mathrm{Cd}$ by peanut husks and peanut husk biochar from aqueous solutions, Ecol. Eng., 87, 240-245(2016).

52. F. Wang, Q. Zeng, W. Su, M. Zhang, L. Hou, Z. L. Wang, Adsortion of bisphenol A on peanut shell biochars: the effect of surfactants, J. Chem, 2019, 2428505(2019).

\section{Declaration of Competing Interest}

The authors declare that they have no known competing financial interests or personal relationships that could have appeared to influence the work reported in this paper.

\section{Authors and Contribution Statement}

\section{Yoonmi Jang}

Department of Civil and Environmental Engineering, Seoul National University, Master Candidate, ORCID (1) 0000-0001-7721-956X: Conceptualization, Data curation, Data analysis, Methodology, Project administration, Validation, Visualization, Writing - original draft.

\section{Yongju Choi}

Department of Civil and Environmental Engineering, Seoul National University, Professor, ORCID () 0000-0002-6187-1446: Conceptualization, Data analysis, Funding acquisition, Methodology, Resources, Supervision, Validation, Writing - original draft, Writing - review and editing.

\section{Kibeum Kim}

Water Cycle Research Center, Korea Institute of Science and Technology, Post-doc, ORCID (C) 0000-0002-2156-488X: Conceptualization, Data curation, Data analysis, Methodology, Supervision, Validation, Writing - review and editing. 